\title{
PENGARUH RESILIENSI DAN RELIGIUSITAS TERHADAP KESEJAHTERAAN PSIKOLOGIS PADA GURU DI PAUD RAWAN BENCANA ROB
}

\author{
Triana Indrawati \\ Institut Agama Islam Negeri Pekalongan, Indonesia \\ trianaindrawati@iainpekalongan.ac.id
}

\begin{abstract}
This study aims to determine the psychological well-being of teachers in early childhood disaster prone to rob in terms of resilience and religiosity. The initial allegation proposed in this study is the resilience and religiosity of psychological well-being of teachers in rob-prone disaster PAUD. The sample in this study were 45 PAUD teachers who were in areas prone to tidal disasters in Pekalongan. Samples were taken using purposive sampling. The measuring instrument used in the study consisted of 3 scales. First, the psychological wellbeing scale compiled based on aspects of Ryff (1989) totaling 26 items with a correlation coefficient of 0.305-0.598 and an alpha coefficient of 0.848. Second, resilience based on aspects of Reivich and Shatte (2002) consisting of 29 items with a correlation coefficient of 0.313-0.625 and an alpha coefficient of 0.896. Third, the scale of religiosity is arranged based on aspects of Glock and Stark (1968) consisting of from 32 items the correlation coefficient is 0.320 to 0.657 and the alpha coefficient is 0.919 . Data analysis method in this research uses multiple regression analysis. Regression analysis results showed $F=103.287$ with $p=0.000$ ( $\mathrm{p}<0.05)$, and $\mathrm{R}^{2}=0.831$ which means resilience and religiosity can predict psychological well-being of teachers in PAUD prone to tidal disasters.
\end{abstract}

Keywords: Early Childhood Teachers prone to tidal disasters, Psychological Wellbeing, Resilience, Religiosity

\begin{abstract}
Abstrak
Penelitian ini bertujuan untuk mengetahui kesejahteraan psikologis pada guru di PAUD rawan bencana rob yang ditinjau dari resiliensi dan religiusitas. Dugaan awal yang diajukan dalam penelitian ini adalah resiliensi dan religiusitas terhadap kesejahteraan psikologis pada guru di PAUD rawan bencana rob. Sampel dalam penelitian ini adalah 45 guru PAUD yang berada didaerah rawan bencana rob di Pekalongan. Sampel diambil dengan menggunakan purposive sampling. Alat ukur yang digunakan dalam penelitian terdiri dari 3 skala.Pertama, skala kesejahteraan psikologis yang disusun berdasarkan aspek-aspek dari Ryff (1989)berjumlah 26 item dengan koefisien korelasi 0,305-0,598 dan koefisien alpha sebesar 0,848 . Kedua, resiliensi berdasarkan aspek-aspek dari Reivich dan Shatte (2002) yang terdiri dari 29 item dengan koefisien korelasi 0,313-0,625 dan koefisien alpha sebesar 0,896.Ketiga, skala religiusitas yang disusun berdasarkan aspek-aspek dari Glock dan Stark (1968) yang terdiri dari 32 item koefisien korelasi 0,320-0,657 dan koefisien alpha sebesar 0,919. Metode analisis data dalam penelitian ini menggunakan analisis regresi ganda. Analisis regresi ganda menunjukan nilai $F=103,287$ dengan $p=0,000(p<0,05)$, dan $\mathrm{R}^{2}=0,831$ yang artinya resiliensi dan religiusitas berpengaruh terhadap kesejahteraan psikologis pada guru di PAUD rawan bencana rob.
\end{abstract}

Kata Kunci: Guru PAUD rawan bencana rob, Kesejahteraan Psikologis,Resiliensi, Religiusitas. 


\section{PENDAHULUAN}

Kejadian atau peristiwa disebut sebagai bencana jika dapat mengancam kehidupan masyarakat secara umum, bias disebabkan oleh faktor manusia itu sendiri, faktor alam, atau faktor yang lainnya. Bencana menimbulkan kerugian dan kerusakan. Kerugian secara materiil, psikologis bahkan bias sampai menelan korban jiwa. Salah satu bencana yang saat ini terjadi dan menjadi fokus pemerintah di jalur pantura adalah bencana rob. Bencana ini disebabkan air laut yang naik ke permukaan sampai ke daratan karena pasangnya air laut.

Bencana rob di Pekalongan sudah terjadi sejak tahun 2010. Baru-baru ini terjadi lagi bencana banjir rob di Pekalongan tepatnya pada tanggal 23 Mei 2018. Banjir rob yang menerjang sebagian kota Pekalongan dinyatakan sebagai kejadian paling parah sepanjang sejarah. Ketinggian air maupun luas wilayah yang terdampak semakin semakin bertambah. Hampir seluruh wilayah langganan banjir rob di Pekalongan Utara dan sebagian wilayah Pekalongan Barat, dilaporkan tergenang banjir rob dengan ketinggian mencapai 1 meter. Daratan yang tergenang rob mencapai 1.363,13 hektar, dengan korban terdampak 20.818 kepala keluarga, sehingga 3.732 jiwa menjadi pengungsi (www.radarpekalongan.co.id. Diakses 13 September 2018).

Dampak dari banjir rob tidak hanya menenggelamkan rumah-rumah penduduk saja tetapi juga fasilitas-fasilitas umum pun ikut terendam oleh banjir tersebut. Salah satu fasilitas umum yang terendam air rob adalah sekolah. Puluhan sekolah di Kota Pekalongan, Jawa Tengah, terendam air rob. Puluhan sekolah ini, terdiri dari PAUD hingga tingkat SLTA. PAUD menjadi salah satu fokus utama penanganan bencana. (www.tribunnews.com. Diakses 13 September 2018) PAUD menjadi fokus utama dalam penangan bencana adalah hal yang wajar karena peserta didik PAUD adalah anak-anak usia dini yang berusia dari 3-7 tahun dimana pada masa tersebut di kategorikan masa kanak-kanak awal (Hurlock, 1991). Lebih lanjut lagi Hurlock (1999) menyatakan bahwa pada fase tersebut di butuhkan lingkungan yang aman dan nyaman bagi pertumbuhan dan perkembangan anak karena fase tersebut adalah periode sensitif dan kritis perkembangan dimana pada masa mempengaruhi pembentukan kepribadian anak dimasa selanjutnya. Ketika berbicara pembentukan 
kepribadian siswa PAUD maka yang menjadi salah satu kunci berhasil atau tidaknya adalah guru.

Guru adalah salah satu tokoh kunci berhasil tidaknya pembelajaran berlangsung khususnya pada jenjang Pendidikan PAUD. Hal tersebut dikarenakan ketertarikan fase usia kanak-kanak awal adalah orang dewasa yang ada disekelilingnya salah satunya adalah guru. Peran guru dalam Pendidikan Anak Usia Dini adalah suatu proses perubahan yang menyangkut tingkah laku atau kejiwaan. Tugas menjadi guru PAUD tidak mudah seperti membalikan kedua tangan banyak sekali tugas, tantangan dan permasalahan yang harus di selesaikan mulai dari 52 persen kualifikasi Pendidikan guru PAUD di Indonesia yang masih SMA, masalah sarana dan prasarana pendidikan yang kurang memadai, serta minimnya tunjangan atau gaji guru PAUD yang masih dibawah Upah Minimun Regional. (www.detiknews.com.id. Diakses 13 September 2018)

Seharusnya, dengan banyaknya permasalahan yang dialami terlebih lagi terdapat permasalahan tambahan berupa bencana banjir rob membuat seseorang tertekan dan memiliki perasaan yang negatif . Akan tetapi pada kenyataanya tidak demikian dengan guru-guru PAUD di daerah Pekalongan yang sekolahnya terendam banjir rob tersebut merasakan perasaan yang tetap positif seperti bahagia, semangat dan sangat menikmati menjadi guru PAUD. Berdasarkan wawancara yang dilakukan pada 9 September 2018 dengan guru berinisial SM guru PAUD WNKT Pekalongan yang menyatakan bahwa tunjangan dan gaji tidak seberapa hanya mendapatkan Rp. 300.000,00 yang masih di bawah UMR Pekalongan dan meskipun sekolahnya menjadi salah satu sekolah yang terendam banjir Rob kemarin. Lebih lanjut guru tersebut mengungkapkan perasaanya yang tetap bahagia dan menikmati menjadi seorang guru PAUD yang tidak seberapa bayaranya. Hal senada juga dikatakan RM seorang guru PAUD PNJNG WTN Pekalongan mengungkapkan sarana dan prasaran sekolah yang masih terbatas tidak menjadi hambatan terlebih lagi sekolah tersebut menjadi sekolah yang terendam banjir rob juga tetap semangat dalam mengajar peserta didik.

Ada banyak faktor yang mempengaruhi kesejahteraan psikologis, sehingga tidak semua orang memiliki tingkat kesejahteraan psikologis yang sama. Penelitian- 
penelitian yang dilakukan Diener mengindikasikan bahwa tidak ada penentu tunggal dari kesejahteraan psikologis. Beberapa kondisi tampaknya diperlukan untuk mencapai kesejahteraan yang tinggi seperti kesehatan mental dan hubungan sosial yang positif (Eid dan Larsen, 2008). Berdasarkan hasil penelitian-penelitian yang telah dilakukan oleh Diener mengenai kesejahteraan maka dapat dikelompokan bahwa resiliensi serta religiusitas merupakan beberapa faktor yang turut berpengaruh dalam kesejahteraan psikologis seseorang (Eid dan Larsen, 2008).

Resiliensi merupakan kemampuan seseorang memberikan respon yang sehat dan produktif saat berhadapan pada trauma dan kasus yang sengsara, sehingga dibutuhkan dalam pengelolaan permasalahan hidup setiap hari (Reivich \& Shatte, 2002). Individu dikatakan berresiliensi ketika dia mampu mengelola emosi positif sehingga dapat melalui masa-masa sulit (Sholichatun, 2012).

Faktor religiusitas adalah faktor yang menyangkut transendensi seseorang mengenai suatu permasalahan hidupnya terhadap Tuhannnya. Tingkat religiusitas seseorang mempengaruhi seseorang dalam memandang suatu permasalahan dalam hidupnya. Wnuk dan Marcinkowski (2012) berpendapat bahwa religiusitas dapat memberikan pengaruh positif terhadap kesejahteraan psikologis melalui penemuan makna hidup dan peningkatan harapan.

Berdasakan ungkapan-ungkapan pada saat wawancara dengan guru PAUD penyintas banjir rob di Pekalongan terungkap bahwa ada dua faktor yang mempengaruhi tercapainya kesejahteraan psikologis yaitu yang pertama, faktor berupa resiliensi guru tersebut. Hal ini terlihat dari ungkapan-ungkapan salah satu guru berinisial MN yang mengajar di PAUD JRK SR Pekalongan menyatakan bahwa dalam menanggapi bencana banjir Rob yang menggenangi sekolahnya tidak perlu berlarut-larut dalam trauma dan cepat bangkit seperti sesegera mungkin membersihkan sisa air rob yang menggenang jika sudah surut. Lebih lanjut MN menyatakan kalau guru berlarut-larut dalam kesedihan dan ketakutan akan trauma banjir rob siapa yang akan menjalankan proses kegiatan belajar mengajar di sekolah karena menurut MN ada siswa yang jauh lebih membutuhkanya.

Kedua, faktor religiusitas guru PAUD. Berdasarkan hasil wawancara dengan guru berinisial DA guru yang mengajar di PAUD TO Pekalongan menyatakan bahwa 
bekerja menjadi guru PAUD adalah hal yang menyenangkan walaupun pendapatanya sedikit karena DA merasa bersyukur karena rejeki itu sudah diatur oleh Tuhan. Lebih lanjut DA menanggapi sekolanya yang terendam banjir rob DA selalu berdoa dan berpasrah karena DA percaya Tuhan tidak akan membebankan hal yang lebih sulit lebih dari batas kemampuan umatnya.

Berdasarkan fenomena-fenomena dan hasil-hasil penelitian terdahulu, peneliti merasa penting untuk meneliti resiliensi dan religiusitas sebagai faktor yang mempengaruhi kesejahteraan psikologis pada guru di PAUD rawan bencana rob di Pekalongan.

Kesejahteraan Psikologis

Ryff (1989) mendefinisikan kesejahteraan psikologis merupakan keinginan seseorang menyelami potensi dirinya secara menyeluruh (Ryff,1989). Keinginan tersebut mampu membuat individu pasrah sehingga kesejahteraan psikologisnya berada dititik rendah atau malah sebaliknya. Sebagian sumber mengarah pada fungsi psikologi positif.

Salah satunya teori Maslow (dalam Lopez \& Snyder, 2007) tentang konsep aktualisasi diri, pandangan Roger (dalam Lopez \& Snyder, 2007) tentang individu yang berfungsi secara penuh). Ryff (1989) mengemukakan enam aspek kesejahteraan psikologi yaitu: penerimaan diri, hubungan positif dengan orang lain, otonomi, penguasaan lingkungan, tujuan hidup, pertumbuhan pribadi. Faktor-faktor yang mempengaruhi kesejahteraan psikologis pada diri individu Eid dan Larsen (2008) yakni: sosiodemografis, kepribadian, dukungan sosial, religiusitas, pengalaman terhadap makna hidup.

Resiliensi

Tugade dan Fredrickson (2004) menyatakan resiliensi adalah kemampuan seseorang dalam hidup, yakni mampu mengatasi permasalahan kehidupan, menjaga kesehatan dan memiliki energy positif dalam hidup sehingga memiliki kualitas hidup sehat. Resiliensi mengarah pada kemampuan seseorang untuk bertahan dan pulih dari suatu permasalahan. Ada yang pulih dari kondisi yang tidak menguntungkan. Ada yang gagal bangkit, adapula individu yang setelah mengalami masalah berat mampu keluar dari permasalahan denagn baik dan melanjutkan hidupnya lebih berkualitas. 
Senada denagn pernyataan sebelumnya, Reivich dan Shatte (2000) menyatakan resiliensi merupakan kemampuan seseorang untuk beradaptasi dan bertahan dalam menghadapi permasalahan. Kemampuan resiliensi membuat seseorang dapat mengatasi suatu perubahan besar yang bersifat mengganggu dan kontinu serta selalu bangkit dari keterpurukan. Hal ini dapat terjadi dengan cara menjaga kesehatan dan memiliki energi (Siebert, 2005).

Terdapat tujuh aspek dari resiliensi menurut Reivich dan Shatte (2002). Aspek yang pertama yaitu pengaturan emosi. Pengaturan emosi seseorang supaya selalu tenang dalam berbagai keadaan. Aspek yang kedua yaitu kontrol. Bagaimana mengontrol impuls atau dorongan yang muncul. Aspek yang ketiga yaitu optimisme. Keyakinan individu bahwa segala sesuatu akan lebih baik daripada sebelumnya. Optimisme merupakan suatu harapan dan kontrol. Aspek keempat adalah kemampuan menganalisis suatu permaslaahan. Individu mampu melakukan analisis suatu masalah melalui identifikasi mendetail sebab suatu permasalahan. Aspek yang kelima, yaitu empati. Kemampuan untuk bisa merasakan dan membaca perasaan oranglain serta bagaimana emosi seseorang. Aspek keenam yaitu efikasi diri. Individu memiliki suatu kepercayaan dan keyakinan diri bahwa individu mampu untuk menyelesaikan segala jenis permasalahan. Aspek ketujuh yaitu kemampuan meraih apa yang diinginkan atau biasa yang disebut dengan pencapaian. Pencapaian atas segala hal positif pada diri dan penyelesaian segala permasalahan dalam kehidupan.

Glock dan Stark (1968) menyatakan bahwa religiusitas adalah tingkat pengetahuan, keyakinan, pelaksanaan ibadah, dan penghayatan seseorang terhadap agamanya. Lebih lanjut agama tersebut bersifat mengikat sehingga harus individu harus memegang teguh dan patuh. Ikatan tersebut merupakan kekuatan gaib yang lebih tinggi daripada kekuatan manusia. Ikatan tersebut tidak dapat dirasakan oleh pancaindera kita namun berpengaruh terhadp kehidupan (Glock dan Stark, 1968). Agama membuat individu yang memeluknya menjadi lebih baik dalam perilakunya, memiliki tanggung jawab atas perbuatannya, serta selalu berusaha untuk menjadi lebih baik lagi.

Glock dan Stark (1968), membagi religiusitas (keagamaan) menjadi lima aspek, yaitu. Aspek yang pertama yaitu keyakinan/ideologi. Dimensi ini berisi pengharapanpengharapan dimana orang religius berpegang teguh pada pandangan teologis tertentu 
dan mengakui kebenaran doktrin tersebut. Aspek yang kedua yaitu praktik agama/peribadatan. Dimensi ini mencakup perilaku pemujaan, pelaksanaan ritus formal keagamaan, ketaan dan hal-hal yang dilakukan orang untuk menunjukkan komitmen terhadap agama yang dianutnya. Ketiga, Pengalaman . Pengalaman keagamaan, perasaan, persepsi dan sensasi yang dialami seseorang atau didefinisikan oleh suatu kelompok keagamaan (atau masyarakat) yang melihat komunikasi, walaupun kecil, dalam suatu esensi ketuhanan yaitu dengan Tuhan, kenyataan terakhir, dengan otoritas transedental. Keempat, pengetahuan agama. Dimensi ini mengacu pada harapan bagi orang-orang yang beragama paling tidak memiliki sejumlah minimal pengetahuan mengenai dasar-dasar keyakinan, ritus-ritus, kitab suci dan tradisi-tradisi.

Kelima, konsekuensi. Dimensi ini mengacu pada identifikasi akibat-akibat keyakinan keagamaan, praktik, pengalaman dan pengetahuan seseorang dari hari ke hari. Dengan kata lain, sejauh mana implikasi ajaran agama mempengaruhi perilakunya. Hipotesis penelitian ini adalah ada pengaruh positif resiliensi dan religiusitas terhadap kesejahteraan psikologis pada guru di PAUD rawan bencana rob.

\section{METODE PENELITIAN}

Subyek dalam penelitian ini adalah guru di PAUD rawan bencana rob Pekalongan. Sampel dalam penelitian ini adalah guru PAUD dari empat kecamatan yang tersebar di empat kecamatan wilayah kota dan kabupaten Pekalongan yaitu PAUD di kecamatan Pekalongan Utara, Wiradesa, Tirto dan Wonokerto Pengambilan sampel dilakukan dengan menggunakan teknik purposive sampling.

Metode pengumpulan data menggunakan instrumen berupa 3 skala sikap yang terdiri dari skala kesejahteraan psikologis yang dikembangkan dari teori Ryff (1989) terdiri atas 26 aitem pernyataan. Kedua, skala resiliensi yang dikembangkan dari Reivich dan Shatte terdiri atas 29 aitem pernyataan. Ketiga, skala religiusitas yang dikembangkan dari teori Glock dan Stark (1968) terdiri atas 32 aitem pernyataan.

Teknik analisis data yang digunakan dalam menguji hipotesis pada penelitian ini adalah analisis regresi ganda. Sebelum dilakukan uji hipotesis, terlebih dahulu dilakukan uji asumsi yang meliputi uji normalitas sebaran, uji liniearitas hubungan 
dan uji multikolinieritas. Uji hipotesis dilakukan dengan bantuan program SPSS (Statistic Package for Social Saince) 17.0 for Windows.

\section{HASIL PENELITIAN DAN PEMBAHASAN}

Penelitian ini bertujuan untuk menguji pengaruh resiliensi dan religiusitas terhadap kesejahteraan psikologis pada guru di PAUD rawan bencana rob. Berdasarkan hasil analisis yang telah dilakukan, hipotesis yang diajukan dapat terbukti kebenaranya yaitu resiliensi dan religiusitas dapat berpengaruh terhadap kesejahteraan psikologis secara bersama-sama. Hal ini dibuktikan dengan hasil analisis regresi yaitu $R$ sebesar 0,912, F sebesar 103,287 dengan $p=0,000(p<0,05)$ dan nilai $\mathbf{R}^{2}=0,831$. Hasil ini menjelaskan bahwa ada peran positif, yaitu semakin tinggi resiliensi dan religiusitas maka ada kecenderungan peningkatan kesejahteraan psikologis pada guru di PAUD rawan bencana rob. Sumbangan efektif resiliensi dan religiusitas dalam meningkatkan kesejahteraan psikologis sebesar $83,1 \%$, sisanya $(16,9 \%)$ dipengaruhi oleh faktor lain yang tidak menjadi fokus penelitian ini.

Hasil penelitian ini sejalan dengan penelitian-peneltian yang dilakukan sebelumnya yang dilakukan oleh Purwanti dan Kustanti (2018). Hasil penelitian dari Purwanti dan Kustanti (2018) menunjukan bahwa resiliensi berhubungan positif dengan kesejahteraan psikologis. Hasil penelitian lain dilakukan oleh Hanantari dkk (2017) pada remaja panti asuhan di kabupaten Banyumas menunjukan bahwa resiliensi adalah salah satu prediktor dalam kesejahteraan subjective.

Resiliensi dibutuhkan guru di PAUD rawan Bencana Rob untuk mengahadapi permasalahan dalam kehidupan baik itu masalah di rumah ataupun di sekolah agar dapat meningkatkan kesejahteraan psikologisnya. Resiliensi merupakan kemampuan untuk beradaptasi dalam mengatasi masalah yang berat. Bertahan dalam suatu keadaan yang menekan dan bahkan hidup dalam kesengsaraan atau suatu trauma yang pernah dialami (Reivic dan Shatte 2002).

Grotberg (1999) menjelaskan bahwa resiliensi sebagai suatu kapasitas individu untuk menangani, menghilangkan bahkan mengubah pengalaman yang tidak menyenangkan termasuk bencana alam atau atau bencana yang dibuat oleh manusia. Resiliensi membantu individu yang hidup dalam kondisi atau pengalaman buruk dengan meningkatkan keyakinan dan harapan yang memadai untuk fungsi social dan 
pribadi yang lebih efektif. Orang yang memiliki resiliensi tinggi mungkin akan tinggi kesejahteraan psikologisnya dibandikan individu yang memiliki resiliensi rendah hal ini dikarenakan individu memiliki ketahanan untuk bangkit kembali dari pengalaman emosi negatif dan mudah beradaptasi dengan perubahan stress secara fleksibel seperti yang dialami oleh guru di PAUD rawan bencana rob seperti perasaan was-was atau teror dihantui bencana rob secara terus-menerus. Resiliensi dianggap menjadi salah satu faktor penting didalam menghandapi bencana tersebut sehingga kesejahteraan psikologis dari guru tersebut dapat meningkat.

Subyek penelitian adalah guru PAUD dimana selain di hantui oleh bencana rob permasalahan lainnya adalah gaji yang masih dibawah UMR (Upah Minimun Regional). Permasalahan ini membuat semakin berat dan dapat membuat emosi guru semakin bergejolak sehingga ketika seseorang tidak mudah bangkit dalam kesengsaraan membuat dirinya semakin terpuruk dan berdampak pada kesejahteraan psikologis individu. Oleh karena itu resiliensi sangat dibutuhkan dalam meningkatkan kesejahteraan psikologis pada guru di PAUD rawan bencana rob.

Individu yang memiliki resiliensi tinggi maka memiliki regulasi emosi dan hal ini yang dapat membuat inividu tetap tenang walaupun dalam kondisi genting yang membuat seseorang tertekan. Selain itu impuls control dari individu yang memiliki reseliensi tinggi juga tinggi sehingga individu dapat dengan mudah meredam emosi dan sabar. Hal ini serupa dengan kondisi subyek penelitian dimana subyek selalu bersabar dan dapat meredam emosi walaupun bekerja dengan gaji yang masih dibawah UMR. Jiwa optimis juga ditunjukan bagi individu yang memiliki resiliensi tinggi. Individu selalu memandang masalah berita buruk selalu memiliki solusi seperti halnya di alami oleh guru di PAUD rawan bencana rob. Guru-guru tersebut selalu memandang bahwa pasti suatu ketika ada solusi atas permasalahan rob yang kerap terjadi di tempat mereka bekerja. Pada kondisi mental positif inilah akan diikuti dengan meningkatkan harga diri yang tinggi dan penerimaan diri yang baik tanpa ada stres akibat tekanan-tekanan dan akhirnya tercapai kesejahteraan psikologis pada guru di PAUD rawan bencana rob.

Religiusitas berperan secara positif terhadap kesejahteraan psikologis Hasil penelitian ini konsisten dengan penelitian sebelumnya yang dilakukan oleh Linawati dan Desiningrum (2017) menunjukan bahwa religiusitas memiliki efek langsung 
terhadap kesejahteraan psikologis. Hasil penelitian lain yang mendukung penelitan ini juga dilakukan oleh Harpan (2006) yang menunjukan religiusitas berpengaruh signifikan dalam meningkatkan kesejahteraan psikologis pada remaja.

Papalia (2001) mengatakan bahwa para ahli meyimpulkan religiusitas sangat berhubungan erat dengan kesejhateraan psikologis. Individu yang memiliki religiusitas tinggi memiliki sikap yang lebih baik dan lebih puas dalam memaknai hidup dan hanya sedikit mengalami kesepian. Lebih lanjut Utami dan Amadyawati (2007) menjelaskan bahwa hubungan antara religiusitas dan kesejahteraan psikologis dikarenakan agama dapat menyediakan sumber-sumber untuk menjelaskan dan menyelesaikan situasi suatu permasalahan. Selain itu agama dapat meningkatkan perasaan berdaya dan mampu pada diri seseorang, agama juga menjadi landasan perasaan bermakna, arah memiliki arah tujuan dan identitas personal sehingga dapat memaknai suatu peristiwa sebagai sesuatu hal yang berarti sehingga dapat tercapainya suatu kondisi kesejahteraan psikologis pada individu.

Seligman (2000) berpendapat bahwa religiusitas berperan penting dalam kehidupan manusia karena nilai yang terkandung didalam religiusitas dapat membawa individu kearah yang lebih baik serta ajaran yang ada didalamnya dapat mengatasi berbagai masalah psikologis sehingga menjadikan seseorang memiliki perasaan yang positif.

Religiusitas dapat memberikan efek perasaan yang bahagia terhadap individu hal ini dirasakan oleh guru di PAUD rawan bencana rob. Beberapa aspek religiusitas terkait langsung dengan kesejahteraan psikologis. Individu yang melakukan praktik peribadatan secara rutin akan memberikan efek yang baik bagi kesehatan mental. Selain itu orang yang memiliki religiusitas yang tinggi memiliki pengetahuan agama dan pengalaman yang baik sehingga selalu memaknai positif setiap musibah yang dialami termasuk bencana rob.

Religiusitas adalah salah satu faktor yang dapat meningkatkan kesejahteraan psikologis. Religiusitas adalah faktor berkaitan dengan transendensi segala persoalan hidup kepada Tuhan. Eid dan Larsen (2008) menyatakan individu yang berpartisipasi dalam kegiatan keagamaan lebih mempunyai kesejahteraan psikologis yang tinggi. 


\section{KESIMPULAN DAN SARAN}

Berdasarkan hasil analisis dan pembahasan maka terdapat beberapa kesimpulan sebagai berikut terdapat pengaruh positif resiliensi dan religiusitas terhadap kesejahteraan psikologis pada guru di PAUD rawan bencana rob sebesar $83,1 \%$. Hasil tersebut berarti semakin tinggi resiliensi dan religiusitas maka ada kecenderungan peningkatan kesejahteraan psikologis pada guru di PAUD rawan bencana rob.

Saran yang dapat peneliti berikan mengenai kesejahteraan psikologis berdasarkan hasil penelitian ini adalah bagi guru yang mempunyai kesejahteraan psikologis yang rendah dan sedang, diharapkan dapat meningkatkannya resiliensi dan religusitas salah satunya dengan cara melatih kemampuan dalam pemecahan masalah serta belajar memperdalam dan mengamalkan ilmu agama. Bagi guru yang mempunyai kesejahteraan psikologis tinggi diharapkan dapat mempertahankanya karena pada penelitian ini terbukti bahwa resiliensi dan religiusitas dapat meningkatkan kesejahteraan psikologis. Bagi peneliti selanjutnya, peneliti menyarankan berdasarkan hasil penelitian yang dilakukan adalah peneliti selanjutnya menggunakan variabel-variabel lainya yang dimungkinkan berkontribusi bagi peningkatan kesejahteraan psikologis pada guru di PAUD rawan bencana rob. Variabel tersebut diantaranya, penilian terhadap pengalaman hidup, optimisme, sosiodemografis, dan religiusitas.

\section{DAFTAR PUSTAKA}

Bernardi. R. (2018).Gelombang tinggi ribuan rumah Pekalongan terendam rob. Diakses dari http//detiknews.com pada tanggal 13 September 2018.

Eid, M. \& Larsen, R. J. (2008). The science of subjective well being. New York: The Guilford Press.

Glock, C. \& Stark, R. (1966). Religion and society in tension. Chicago: Universityof California.

Harpan, A. (2006). Pusat kendali, optimisme, dan kesejahteraan psikologis pada remaja. Tesis (tidak diterbitkan). Yogyakarta: Universitas Gadjah Mada

Linawati, A.R, \& Desiningrum, R.D. (2017). Hubungan antara religiusitas dengan psychological well-being pada siswa smp Muhammadiyah 7 Semarang. Jurnal Empati Vol 7 (2).

Papalia, D. E, Olds, S. W, \& Feldman, R.D. (2008). Human development. Boston: MC Graw Hill.

Reivich, K \& Shatte, A. (2002). The resillience factor. New York : Broadway Books. 
Ryff, C. D.(1989). Happiness is everything, or is it? Exploration on the meaning of psychological well-Being. Journal of Personality and Social Psychology, 57(6), 1069-1081.

Santoso. B. (2018) 1.363,13 Hektar Wilayah Kota Pekalongan Terendam Air Rob. Diakses dari http//tribunnewsjateng.com pada tanggal 13 September 2018.

Seligman, M. E. P., \& Csikszentmihalyi, M. (2000). Positive psychology: An introduction. American Psychological Association, 55(1), 5-14.

Solichatun, Y. (2012). Hidup setelah menikah , mengurai emosi positif dan resiliensi pada wanita tanpa pasangan. Jurnal Egalita Vol 4 (1).

Tugade. M.M \& Fredrickson, B.I. (2004). Resilient individuals use positive emotions to bounce back from negative emotional experiences. Journal of Personality and Social Psychology vol. 86, no.2, 320-333

Utami, S.M, \& Amawidyawati, S.A.G ( 2007). Religiusitas dan psychological wellbeing pada korban gempa. Jurnal Psikologi Universitas Gadjah Mada Vol 34 ( 2).

Wnuk, M., \& Marcinkowski, J. T. (2012). Do existential variables mediate between religious-spiritual facets of functionality and psychological wellbeing. Journal Religius Health. 7(4),27-36. 